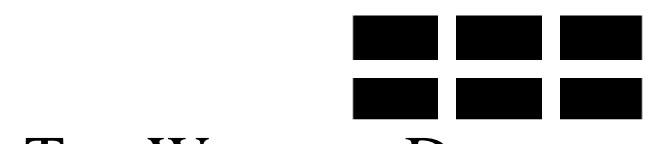

THE WILLIAM DAVIDSON INSTITUTE AT THE UNIVERSITY OF MICHIGAN BUSINESS SCHOOL

\title{
Reform, FDI and Economic Growth: Tale of the Tortoise and the Hare
}

By: Bruno Merlevede and Koen Schoors

William Davidson Institute Working Paper Number 730

November 2004 


\title{
Reform, FDI and Economic Growth: Tale of the Tortoise and the Hare
}

\author{
Bruno Merlevede* \\ Department of Economics \& CERISE \\ Ghent University \\ Koen Schoors \\ CERISE, Ghent University and WDI
}

October 2004

\begin{abstract}
Our main interest is the impact of the choice of the speed of economic reform on economic growth. We estimate a system of 3 equations where economic growth, economic reform and FDI are jointly determined. We find that new reforms affect economic growth negatively but attract FDI, whereas the level of past reform leads to higher growth. This means that the immediate adjustment cost of new reforms is counterbalanced by an immediate increase in FDI inflows and higher growth in the future through a higher level of past reform. Reform reversals contribute to lower growth. We use the model to simulate the impact of big bang reform and gradualist reform on economic growth. This is only meaningful in the presence of reform reversals, which requires aggregate uncertainty about the appropriate reform path. Using the coefficients from the empirical model we find that even relatively small ex ante reversal probabilities suffice to tilt the balance in favour of gradualism. This could be reinforced by the shortsightedness of policymakers, but may be moderated by voter myopia.
\end{abstract}

JEL Classification: O57, P21, P26, and P27

Keywords: policy reform, gradualism, big bang, FDI, economic growth

\footnotetext{
${ }^{*}$ Corresponding author: CERISE - Centre for Russian International and Socio-Political and Economic Studies, Ghent University, Hoveniersberg 24, B-9000 Ghent, Belgium; tel.: +32-9-264.35.03; fax: +32-9264.35.99; bruno.merlevede@ugent.be
} 


\section{Introduction}

The optimal speed of policy reform has been the subject of heated debate. The World Bank and even more so the International Monetary Fund have in the past been promotors of swift reform. The IMF's conditionality of its short term stand-by agreements has often demanded quick reform on the part of the receiving government. The crises of the last 10 years have, however, shaken this belief in quick reform and brought home the message that sequencing may be more important than previously thought. The old message of quick and unconditional capital account liberalisation for example, has not been without its problems. It is now widely recognised that successfull capital account liberalisation requires at least well-established and stable domestic financial markets. The experience of developing and emerging market economies has stressed with increasing success that gradual reform ought to be preferred over shockwise reform. There is, however, disturbingly little evidence on the specific relation between reform and growth, as noted by Skogstad and Everhart (2001). They study a set of developing countries and find empirical indications that the sequence and the magnitude of policy reform is related to economic growth.

In this paper, we go one step further by looking at the interaction between economic reform, economic growth and FDI. This allows us to disentangle some of the mechanisms through which reform affects growth. Rather than analysing the traditional set of developing countries, we focus on a panel of 25 transition countries. Transition countries exhibit a high, but varying speed of economic reform, they also experienced substantial, but varying inflows of FDI. This makes them perfectly suited to study the impact of the speed of reform on economic growth. The paper, however, is not so much about transition but about the relation between reform, FDI, and growth. We believe therefore that the main message of the paper, namely that the case for gradualism is better than generally perceived, is applicable to emerging market and developing economies alike.

The debate on the speed of economic reform surged at the start of transition when the economic profession was called upon for policy advice. Two broad streams of thought emerged, namely shock therapists, who advocated radical reforms and rapid transformation, and gradualists, advocating a more cautious and piecemeal approach to reform. Roland (2000) brings most of the theoretical work together and develops different models of transition. He derives that gradualism can only dominate a big bang strategy with respect to economic growth in the presence of aggregate uncertainty and reversal costs. The empirical growth-in-transition literature initially neglected the cost of reform reversals. The standard empirical framework even imposed a short-lived positive effect of a reversal (see a.o. Åslund et al. (1996), De 
Melo et al. (1996), Fischer et al. (1996a,b), De Melo et al. (1997), Krueger and Ciolko (1998), Berg et al. (1999), Heybey and Murrell (1999), Falcetti et al. (2002)). This implied that economic growth was always higher with big bang reforms than with gradualist reforms. According to this line of work, some of which has been done by the IMF and the WB, more reform is always better. This was in stark contrast with theory and with the stylised fact that most policymakers did not opt for big bang policies. Merlevede (2003) showed that reversals are indeed costly and brought the empirical literature back in line with theory and stylised facts.

This paper contributes to this line of research in two distinct ways. First, the effect of growth and reform on FDI and vice versa has been largely neglected. We adress the potential endogeneity of FDI and reform efforts in the growth equation by estimating a 3SLS-system with growth, reform, and FDI as dependent variables that are allowed to influence one another contemporaneously. Second, the estimated coefficients of this more general model are employed to simulate the effect of a reform reversal on economic growth for an average transition country that either follows a big bang or a gradualist reform path. This allows us to draw conclusions on the choice between gradualism and big bang in the real world. We find that for an average transition country, the choice for gradualism is more likely than the choice for big bang. We also show how political cycles and voter myopia might influence the policymaker's choice between big bang and gradualism.

In the next section we build and estimate the econometric model. Section 3 simulates and discusses the economic effects of big bang and gradualism in the presence of reform reversals. Section 4 provides policy implications and concludes.

\section{Reform, Growth and FDI}

\subsection{Methodological approach}

In our view of the world, reform choices are the result of a politically constrained decision process affected by economic variables. They are not independent decisions (see Campos and Corricelli, 2002). The failure to consider the feedback of growth and initial conditions on reform will bias the estimated impact of reform on growth. Equivalently FDI are an important determinant of economic growth, but may in turn be influenced by economic growth and reform. In short, reform, FDI and growth may be endogenous to one another. We will therefore estimate a system of 3 simultaneous equations where economic growth, economic reform and FDI are jointly determined. 
As regards the growth and reform regressions, the literature on empirical growth in transition (see introduction) has employed three categories of explanatory variables, namely macroeconomic stabilisation, initial conditions and policy reform. Macroeconomic stabilization in the form of consumer price stabilisation, often achieved through an exchange rate peg or budgetary discipline, is found to be beneficial to economic growth. Initial conditions account to a substantial degree for the variation in economic performance at the start of transition, but their importance diminishes over time. Finally, policy reform brings economic growth through improved allocational efficiency. Most authors agree that the lagged level or the 'stock' of reform has a robust positive impact on growth and that new reforms have a negative impact on economic growth, albeit not always significant. In general, the level of reform, measured by a reform index RI, enters the growth equation in the following way: $\alpha R I_{t}+\beta R I_{t-1}$, where we expect $\alpha<0, \beta>0$ and $|\alpha|<\beta$. Rewriting this expression as $\alpha \Delta R I_{t}+(\alpha+\beta) R I_{t-1}$, reveals that new reforms $\left(\Delta R I_{t}\right)$ entail an immediate adjustment cost in terms of lower growth but also bring future positive $(|\alpha|<\beta)$ growth through a higher stock of reform $\left(R I_{t-1}\right)$. But if $\alpha<0$, a reform reversal $\left(\Delta R I_{t}<0\right)$ generates an instantaneous positive effect on growth, slowing growth only the following year through the lower stock of reform. This was precisely the problem of the early growth in transiton literature, because the positive effect of reversals is in contradiction with the theoretical literature that requires costly reversals to retain gradualism as a policy option. We therefore allow that reform reversals have a separate coefficient in the growth equation, as in Merlevede (2003).

FDI is of particular importance in developing countries, but its joint relation with growth and reform has remained largely unstudied. The recent growth literature has highlighted the dependence of growth rates on the state of domestic technology relative to that of the rest of the world. In a typical model of technology diffusion, the rate of economic growth of a backward country depends on the extent of adoption and implementation of new technologies that are already in use in leading countries (Borensztein et al., 1998). FDI is for developing countries a crucial channel to generate technology spillovers. Although there is ample theoretical work on the relation between FDI and economic growth, empirical confirmation has been scant. Borensztein et al. (1998) showed that the effect of FDI is conditional on a sufficient level of absorptive capacity. In contrast to the result of Borensztein et al. (1998), Lensink and Morrissey (2001) find a consistent positive impact of FDI and a negative impact of the volatility of FDI on economic growth. They find that the positive effect is not sensitive to other variables. Bengoa and Sanchez-Robles (2003) explore the relationships between FDI, economic freedom and economic growth for a panel of Latin 
Amercan countries. They find that economic freedom increases FDI inflows (as percentage of GDP) and that both economic freedom and FDI have a positive impact on growth. Part of the impact of economic freedom on growth is therefore indirect, namely through increased FDI inflows. Campos and Kinoshita (2002) argue that transition provides a good context to test the effects of FDI. Transition countries were typically far from the technological frontier, but, in contrast with most developing countries, started with an industrial structure and a relatively educated labour force. This makes the transition countries more receptive to technology diffusion by means of FDI. Campos and Kinoshita (2002) find a significant positive impact of FDI on economic growth that is not conditional on any level of human capital, but they do not consider possible interactions with economic reform.

\subsection{Empirical framework and data}

We estimate specification (1) below:

$$
\begin{aligned}
\Delta G D P_{i, t}= & \alpha_{0}+\alpha_{i}+\alpha_{1} R I_{i, t}+\alpha_{2} R I_{i, t-1}+\alpha_{3} R I_{i, t-1} \Delta R I_{i, t} D_{i, t} \\
& +\alpha_{4} t I C_{1}+\alpha_{5} t I C_{2}+\alpha_{6} G G B_{i, t}+\alpha_{7} f d i_{i, t}+\varepsilon_{i, t} \\
R I_{i, t}= & \beta_{0}+\beta_{i}+\beta_{1} \Delta G D P_{i, t}+\beta_{2} \Delta G D P_{i, t-1}+\beta_{3} F S_{i, t} \\
& +\beta_{4} t I C_{1}+\beta_{5} t I C_{2}+\eta_{i, t} \\
f d i_{i, t}= & \gamma_{0}+\gamma_{i}+\gamma_{1} \Delta G D P_{i, t}+\gamma_{2} R I_{i, t}+\gamma_{3} t \\
& +\gamma_{4} N A T R E S+v_{i, t}
\end{aligned}
$$

Real GDP-growth (domestic currency) in (1) is related to a constant, a country-specific effect, two indicators of initial conditions IC1 and IC2 (these are taken from De Melo et al., 1997) multiplied by a linear time trend ${ }^{1}$, the general government balance, the logarithm of foreign direct investment inflows, current reform, lagged reform and finally a reversal variable $R I_{i, t-1} \Delta R I_{i, t} D_{i, t}$. The dummy variable $D_{i, t}$ takes the value 1 if a reversal occurs and 0 otherwise and $\Delta R I_{i, t}$ is the change in the aggregate reform index (new reform). The specification $R I_{i, t-1} \Delta R I_{i, t} D_{i, t}$ reflects the assumption that that the cost of a reversal is related to the reversal's magnitude and to the magnitude of the stock of reform at the time

\footnotetext{
${ }^{1}$ The level effect of IC1 and IC2 is captured by the country-specific effect.
} 
of the reversal. The more reform has been achieved the more costly reversals become. As stabilization variable we choose the general government balance. Campos and Corricelli (2002) argue that inflation is a policy result, whereas the fiscal balance refers more to the policy itself. The second equation specifies the level of reform as a function of a countryspecific effect, current and lagged real GDP growth, initial conditions interacted with a time trend, and the freedom status (FS). The freedom status is calculated as the average of the ratings on the Freedom House political liberties and the civil rights indexes. For the sake of clarity, we use the inverse of the original indicator to have a variable that increases with political liberties and civil rights. Hence, we expect a positive value for $\beta_{3}$. The third equation specifies FDI inflows as a function of a country-specific effect, real GDP growth, the level of reform, and an indicator of the availability of natural resources in the country (rather than the clusters of different initial conditions). The country-specific effect will capture market size and other unknown country-specific effects. As indicator of reform $R I_{i, t}$, we use the EBRD index of structural reform that is kept for 25 transition countries. Detailed data definitions and data sources are given in Appendix A. The usual caveats about data on transition countries apply.

We estimate (1) by a three stage least squares estimator (3SLS). Since the disturbances in the equations are correlated with the endogenous variables, which are also the dependent variables in the other equations, the OLS assumptions are violated. Because the endogenous variables are also the dependent variables of the other equations the error terms among the equations are expected to be correlated. 3SLS then uses an instrumental variables approach to produce consistent estimates and a generalised least squares estimation to account for the correlation structure in the disturbances across the equations.

\subsection{Results and interpretation}

The results are presented below (we do not report the country dummies): 


$$
\begin{aligned}
& \Delta G D P_{i, t}=\underset{(0.39)}{5.09}-\underset{(-1.66)}{18.57} R I_{i, t}+\underset{(2.98)}{15.32} R I_{i, t-1}+\underset{(2.06)}{8.54} \Delta R I_{i, t} D_{i, t} R I_{i, t-1} \\
& +\underset{(5.10)}{0.91} t I C_{1}-\underset{(-0.28)}{0.07} t I C_{2}+\underset{(2.73)}{0.26 G G B_{i, t}}+\underset{(2.43)}{5.64} f d i_{i, t} \\
& \mathrm{R}^{2}=0.43 ; \chi^{2}=291.6^{* * *} ; \mathrm{n}=253 \\
& R I_{i, t}=\underset{(8.24)}{1.83}+\underset{(13.00)}{0.056} \Delta G D P_{i, t}-\underset{(-1.54)}{0.005 \Delta G D P_{i, t-1}} \\
& +\underset{(3.30)}{0.98 F} S_{i, t}-\underset{(-4.43)}{0.03} t I C_{1}+\underset{(0.35)}{0.004 t I C_{2}} \\
& \mathrm{R}^{2}=0.74 ; \chi^{2}=918.1^{* * *} ; \mathrm{n}=253 \\
& f d i_{i, t}=-\underset{(-0.44)}{0.36}+\underset{(3.35)}{1.11} R I_{i, t}-\underset{(-0.37)}{0.006} \Delta G D P_{i, t} \\
& +1.06 \text { NATRES + 0.15t } \\
& \text { (4.06) (5.27) } \\
& \mathrm{R}^{2}=0.84 ; \chi^{2}=1290.4^{* * *} ; \mathrm{n}=253
\end{aligned}
$$

As regards the effect of reform on growth, current reform has a negative effect, while lagged reform affects real output growth positively: $-18.57 R I_{i, t}+15.32 R I_{i, t-1}$. At first sight the negative current effect seems to dominate the positive lagged effect. However, taking into account the positive impact of current reform through FDI, we obtain ${ }^{2}:-12.31 R I_{i, t}+$ $15.32 R I_{i, t-1}$, which shows that the positive 'stock' effect of reform dominates the short term adjustment cost. Rewriting yields $-12.31 \Delta R I_{i, t}+3.01 R I_{i, t-1}$. This would imply that reform reversals $\left(\Delta R I_{t}<0\right)$ generate a counterintuitive instantaneous positive growth effect in period $t$, were it not for the independent reversal effect $8.54 \Delta R I_{i, t} D_{i, t} R I_{i, t-1}$ that ensures a negative impact of a reversal ${ }^{3}$. The growth rate is strongly and significantly influenced by an increase in FDI inflows: $5.64 f d i_{i, t}$. This specification clarifies that the positive effect of reform on economic growth, found in earlier studies, partially runs through the positive effect of reform on FDI. Further results are in line with expectations. Better initial conditions, i.e. a higher value of IC1, contribute to growth, and improvements in the general government balance (GGB) are found to be beneficial to growth. The positive coefficient on the interaction between the time trend and IC1 implies diverging growth rates: countries with better initial conditions will grow faster and faster than the countries with more adverse initial conditions.

\footnotetext{
${ }^{2}$ i.e. $-18.57 R I_{i, t}+5.64 * 1.11 R I_{i, t}+15.32 R I_{i, t-1}$

${ }^{3}$ This negative immediate effect of a reversal occurs as soon the stock of reform reaches the value of 1.3. Since the RI-index takes values from 1 to 4.3 with steps of about $\frac{1}{3}, 1.3$ is exactly the lowest value at which a reversal could occur. A reversal therefore always has a negative impact.
} 
The level of the reform index is positively related to current real GDP-growth and the freedom status (FS). The time interacted IC1 has a statistically significant negative impact on reform, offsetting the divergent direct impact of IC1 on growth. Lagged growth has a negligible negative impact on reform. For the determinants of FDI, we find a significant positive impact of the stance of reform and an upward time trend. Countries that have better natural resources receive more FDI inflows. Real GDP growth seems not to affect FDI inflows. The latter finding is in line with Campos and Kinoshita (2002) who show that growth does not Granger-cause FDI inflows in their sample of 25 transition countries. We also tested whether a reversal would have an impact on FDI-inflows. The results presented in Appendix B show that there is no significant impact.

For the simulations in the next section we use a mildly simpler model. We drop real GDP growth as a determinant of FDI inflows, because it is not significant. We also drop the insignificant interactions with IC2, which is in line with Falcetti et al. (2002) who also find that only their first principal component is significant. The specification used for the simulation is presented below:

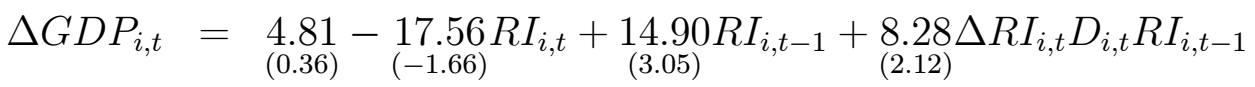

$$
\begin{aligned}
& +\underset{(5.63)}{0.88 t I C_{1}}+\underset{(2.87)}{0.25 G G B_{i, t}}+\underset{(2.77)}{5.40} f d i_{i, t} \\
& \mathrm{R}^{2}=0.45 ; \chi^{2}=310.9^{* * *} ; \mathrm{n}=253 \\
& R I_{i, t}=\underset{(9.92)}{1.78}+\underset{(12.77)}{0.056} \Delta G D P_{i, t}-\underset{(-1.44)}{0.004} \Delta G D P_{i, t-1} \\
& +\underset{(3.19)}{1.01} F S_{i, t}-\underset{(-4.38)}{0.03} t I C_{1} \\
& \mathrm{R}^{2}=0.74 ; \chi^{2}=816.3^{* * *} ; \mathrm{n}=253
\end{aligned}
$$

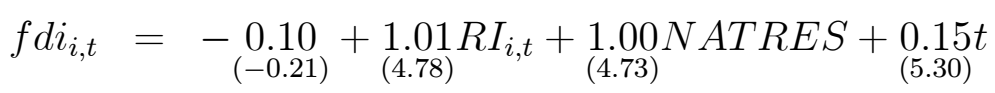

$$
\begin{aligned}
& \mathrm{R}^{2}=0.84 ; \chi^{2}=1312.5^{* * *} ; \mathrm{n}=253
\end{aligned}
$$

\section{Gradualism versus big bang}

\subsection{Simulations}

The estimates of model (3) are now employed to simulate real economic growth under gradualist (GR) and big bang (BB) strategies for the average transition country. This means 
that we take the average of the exogenous variables and the country fixed effects for the simulations. First, we assume a big bang and a gradualist reform path without reversals that both lead to full reform after 8 years. The reform index paths are forced on the model by adding policy shocks to the 2 nd equation of (3), such that we arrive at the gradualist and big bang paths shown in the lower left panel of figure 1. We assume that the choice between GR and BB depends solely on the simulated real economic growth. The effect of reform on

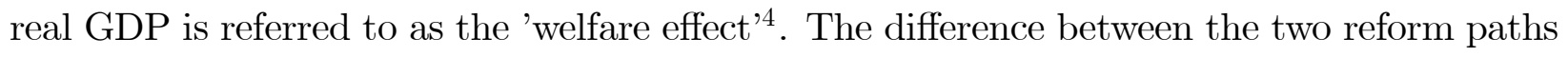
is the timing of reform, the eventual level of reform is the same. We use these assumptions to simulate economic growth under both strategies, using 1000 stochastic replications of (3). The implied output paths are shown in the upper left panel of figure 1. Flat lines represent gradualism and diamond lines represent big bang in both panels. Both output paths are surrounded by a $90 \%$ confidence interval.

We repeat this exercise for the case of a reform reversal. The reversal is implemented as an exogenous reform shock to the second equation of (3). We focus on a reversal to a specific level of the reform index at time $t+2$, which is our interpretation of the return to a conservative platform (see Dewatripont and Roland, 1995) ${ }^{5}$. The reform paths of gradualism and big bang in the presence of a reform reversal are shown in the bottom right panel of figure 1 . We again use these reform paths to simulate economic growth. The implied output paths are shown in the upper right panel of figure 1.

In the no reversal case (the left panel) the real GDP-path is initially lower for big bang (diamond line) because of higher adjustment costs, but after four years the big bang path exceeds the gradualist path $^{6}$ (the flat line). In the right panel with a reversal at time $t+2$ the situation is quite different: under a big bang strategy, the reversal comes at a devastating cost. The loss of growth is so massive that the higher growth rates later in transition induce only a negligible catch-up effect and the gradualist path is not reached in our time window. A switch from big bang to a more gradual approach after the reversal would only reinforce this result. The confidence intervals of big bang and gradualism do not cross, even not at the end of transition. Intuitively, big bang reforms may lead quickly to a high stock of

\footnotetext{
${ }^{4} \mathrm{~A}$ social welfare function that is linear in real GDP would allow to use these terms interchangeably.

${ }^{5}$ Specifically we assume at $t+2$ a return to a conservative level of the Reform Index of 2 , which implies that there is a small reversal for gradualism and a large one for big bang. Simulating a later reversal $(t+3$ until $t+5)$ gives comparable results. Simulating a reversal in the last years $(t+6$ until $t+8)$ is trivial, because in this case there is hardly any difference between big bang and gradualism in terms of the magnitude and hence the cost of reversals, which means that big bang will always be better. This derives from the assumption that both gradualism and big bang arrive at full reform after 8 years.

${ }^{6}$ Assuming that once a score of 4.3 is reached the 'traditional' growth literature takes over, BB will be ahead of GR for a few more years before catch-up.
} 

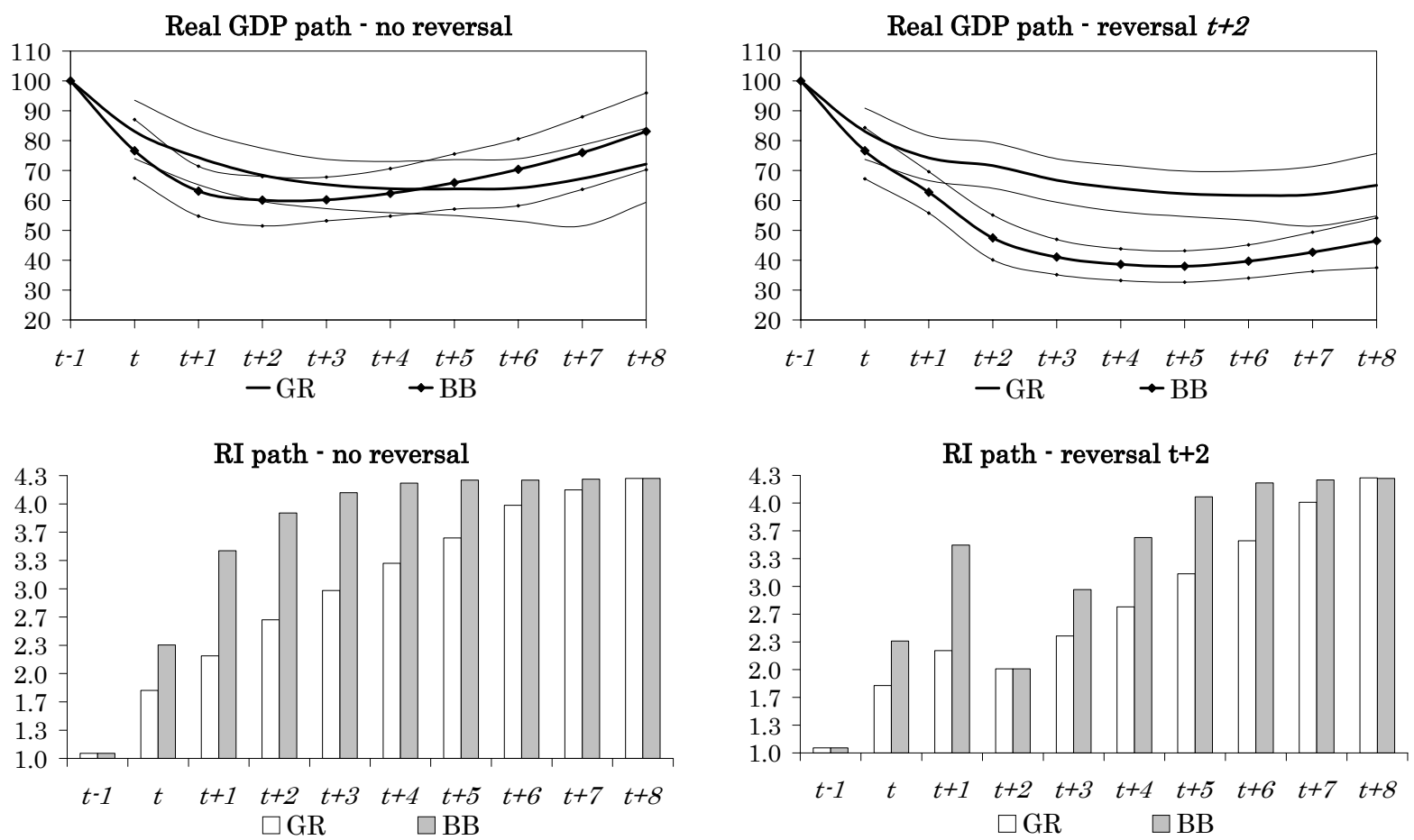

Figure 1: Simulated real GDP and reform paths - no reversal versus reversal at t+2 (90\% confidence intervals in top panels)

reform, which is good for growth, but this is counterbalanced by the fact that a reversal to a conservative platform will be larger and hence much more costly for big bang than for gradualism.

If it is known beforehand whether a reversal will occur or not and there is no uncertainty regarding the output paths, the choice between big bang and gradualism is trivial for a policymaker that maximizes long term economic welfare: without reversal, the big bang strategy will be applied as shown in the left panel; with a reform reversal, the gradualist strategy is preferred, as shown in the right panel.

\subsection{Aggregate Uncertainty}

Roland (2000) stresses the role of uncertainty in policy choice. Policymakers do not have perfect foresight about the appropriate direction of reform, i.e. they cannot know with certainty whether a reversal will occur or not. In our framework uncertainty means that 
policymakers have imperfect information about the type of reform best fit for their country ${ }^{7}$ Some reform steps may turn out to be inappropriate or inconsistent with other reforms. Reversals are then interpreted as a normal component of the trial and error process in search of the appropriate market economy model. The choice between gradualism and big bang at the start of transition will then depend on the expected probability of a future reversal (hence aggregate uncertainty). The degree of uncertainty can be understood as a barrier to immediate big bang reform. Without uncertainty, there will be no reversals and immediate big bang ${ }^{8}$ is optimal.

Reform policies are decided at the beginning of transition in function of ex ante expectations about future reform reversals. The level of aggregate uncertainty in the eye of the policymaker will therefore determine her choice. Table 1 reports the minimal ex ante probabilities that a policymaker should assign to a reversal in a specific year in order to prefer gradualism at the start of transition. We look at three possible criteria policymakers may use to make this choice. In line 1, the policymaker focuses on the GDP-level at the end of transition $T^{9}$. If policymakers only care for the level of real GDP at the end of transition, the expected probability of reversal should be about 0.3 to opt for gradualism. In line 2 (3) the policymaker focuses on the cumulated (cumulated discounted) GDP-levels until the end of transition $T$. Now even lower ex ante reversal probabilities (not higher than 0.2 ) will tilt the policymaker's decision in favour of gradualism. In line 2 and 3, the reversal probability needed to prefer gradualism tends to increase if the reversal is expected later. Indeed, further down in transition the levels of reform converge, and so do the costs of reversal that drive the difference between gradualism and big bang in our simulation. This can also be seen from the bottom left panel in figure 1. Initially the big bang reforms run ahead, but from $t+4$ onwards the reform gap narrows and the costs of reversal converge, essentially because big bang reforms hit the ceiling of maximum reform. Also, the weight of the initial adjustment cost of a big bang reform in cumulated GDP decreases if we are further down the road of transition.

It is concluded that, if policymakers care about cumulated or cumulated discounted welfare during transition, then surprisingly low levels of aggregate uncertainty, as reflected

\footnotetext{
${ }^{7}$ Market economies are characterised by a set of core characteristics but many varieties exist. A score of 4.3 on RI can be interpreted as 'a score equivalent to a market economy', without telling the exact type.

${ }^{8}$ Immediate big bang means that reform immediately jumps to full reform (reform index 4.3). This leads to maximum economic growth because the stock effect.dominates and is immediately maximized.

${ }^{9}$ The end of transition is defined as the second year with a score of 4.3 for the reform indicator for gradualism, the slowest reform policy. This allows the stock effect of reform to mature. See also the notes with Table 1.
} 


\begin{tabular}{lcccc}
\hline \hline criterion $\backslash$ timing of reversal & $t+2$ & $t+3$ & $t+4$ & $t+5$ \\
\hline 1. $G D P_{T}$ & 0.33 & 0.33 & 0.31 & 0.34 \\
2. $\sum_{t=-1}^{T} G D P_{t}$ & 0.08 & 0.08 & 0.12 & 0.20 \\
3. $\sum_{t=-1}^{T} 0.95^{t+1} G D P_{t}$ & 0.02 & 0.03 & 0.08 & 0.16 \\
\hline \hline
\end{tabular}

Table 1: Minimum probability assigned to reversal to prefer gradualism to big bang. (Underlying RI-paths are obtained by taking the no reversal-path from figure 1 until the time of the reversal and completing it with the reversal-part of the reversal-path from then on; the no reversal-paths are extended by adding extra years with a score of 4.3, the latter results in the same growth rates for both GR and BB; criterion: line 1 - GDP-level at the end of transition, line 2 (3) - cumulative (cumulative discounted) GDP-levels until the end of transition.)

in the expected probability of reversal, are sufficient to tilt the balance in favour of gradualism for the average transition country. Even if policymakers care only about economic welfare at the end of transition, reversal probabilities below $35 \%$ suffice to guide them towards gradualism. For the average transition country, the case for gradualism seems therefore rather strong and it may take very hard-nosed reformers to opt for a big bang strategy. The economic intuition is simple: if you don't know which way to run, it may be wise to run a bit slower in order to limit the cost of having to return on your steps.

\subsection{Politics}

In the previous paragraph we looked at a benevolent social welfare planner whose horizon extended to the end of transition. Policymakers are, however, subject to political constraints that may give rise to political cycles in policy making (see Alesina and Roubini, 1992; Persson and Tabellini, 2000). Political constraints make politicians prefer current to future welfare to an extent that exceeds the normal discount factor. The reason is that future welfare may only be enjoyed after the next election and may therefore not be included in the politicians' utility function. The standard democratic political cycle spans 4 years at best, but in transition countries it was on average even shorter. Since reform packages have an impact on future real GDP, their design by politicians in transition countries is subject to severe political constraints (see Dewatripont and Roland, 1992). We will address this probem in a very simple and intuitive way, by assuming that the opinion of voters at the expected time of election matters instead of welfare at the end of transition.

As a starting point assume that voters, and hence politicians, care for aggregate economic welfare, i.e. the level of real GDP, at the time of the election. Assume also that at the time of the policy decision, the time of elections is a maximal span of 4 years away. So the only thing 
that matters is the ex ante expected economic welfare at $t+4$ under both policy scenarios. In the reversal case (see right panel of figure 1) gradualism dominates big bang, while in the no-reversal case (left panel of figure 1) real GDP under big bang exceeds that of gradualism only from $t+5$ on. If the elections take place at $t+4$ or earlier, then policymakers will always prefer gradualism to big bang, even if the probability of a reversal is zero. Should the first elections take place at $t+5$, a very unlikely event, we calculated that the ex ante expected probability of a reversal at time $t+2$ should be below 0.096 for big bang to be preferable. For reversals at time $t+3$ and $t+4$, the corresponding values are 0.079 and 0.083 .

Alternatively we could assume that voters have a memory and thus care about cumulated economic welfare until the time of election. The positive results of the big bang strategy will then materialize even later in transition. Our calculations (not reported here) indicate that cumulated welfare under a big bang policy only exceeds that of gradualism in $t+8$. Even if the first elections were to take place only in $t+8$, extremely small reversal probabilities would still be sufficient for big bang to be preferred. For reversals at $t+2$ the probability should be less than 0.005; at time $t+3$ and $t+4$, the corresponding value is 0.004 . In short, if you take into account political cycles, tiny levels of policy uncertainty are sufficient to tilt the balance in favour of gradualism and big bang strategies seem to belong to the realm of the unreal. These results prompt policymakers to opt for gradualism, unless they do not care for their political survival.

However, differences in economic welfare may be the wrong political criterion. Since voters only observe the outcome of the chosen strategy, not of the alternative, they are imperfectly informed too and therefore not able to compare both strategies' economic welfare. Because it is clearly observed, the turning point from negative to positive growth might be a better criterion for voter behaviour, and hence policymakers' behaviour. Assume that voters leave the incumbent policymakers in power only if the turning point has been reached by the time of the election. Table 2 reveals that a big bang strategy now offers better prospects for re-election. Indeed, under big bang growth rates become positive earlier than under gradualism, both in the reversal and the no-reversal case. More importantly, in the no reversal case big bang policies deliver positive growth rates within the standard political cycle of four years, while gradualist policies fail to do so.

Thus, although the shortsightedness of policymakers drives them towards gradualism, their awareness of imperfect information in the voter's eye has a countervailing effect and may encourage them to gamble for a big bang without a reversal. This table does not bring good news for incumbent policymakers in an average country. If voters are myopic, gradualist 


\begin{tabular}{rccccccc}
\hline \hline & $t$ & $t+1$ & $t+2$ & $t+3$ & $t+4$ & $t+5$ & $t+6$ \\
\hline No reversal & & & & & & & \\
Big bang & -23.4 & -17.4 & -4.5 & $\mathbf{0 . 5}$ & 3.8 & 5.9 & 6.9 \\
Gradualism & -16.9 & -10.3 & -7.7 & -4.3 & -1.9 & $\mathbf{0 . 1}$ & 0.7 \\
Reversal & & & & & & & \\
Big bang & -23.4 & -17.8 & -24.4 & -13.2 & -5.7 & -1.4 & $\mathbf{4 . 6}$ \\
Gradualism & -16.9 & -10.5 & -3.4 & -6.6 & -3.9 & -2.6 & -0.7 \\
\hline \hline
\end{tabular}

Table 2: Real GDP growth rates implied by the simulations

policymakers are not reelected and big bang policymakers are also set to loose power in case of a reversal. The only way to maintain power is to gamble for a big bang and to steer clear of major mistakes and the reversals that come with them. But this may come at a high political and economic cost if a reversal turns out to be necessary anyhow.

\section{Conclusions}

Our main interest is the impact of the speed of economic reform on economic growth. We estimated a system of 3 equations where economic growth, economic reform and FDI are jointly determined. We found that new reforms affect economic growth negatively but attract FDI, while the level of past reform leads to higher growth. FDI are also attracted by improved levels of reform, but not by growth. This means that the immediate adjustment cost of new reforms is counterbalanced by an immediate surge of FDI inflows and higher growth in the future through a higher stock of reform. Reform reversals on the other hand are found to contribute to lower growth.

We use the model to simulate the impact of big bang and gradualist reform on economic growth. This is only meaningful in the presence of reform reversals. If we know whether a reversal will occur or not, the choice between big bang and gradualism is trivial for a benevolent policymaker that maximises long term economic welfare: without reversal, the big bang strategy will be applied, with a reform reversal, the gradualist strategy is preferred. In the presence of uncertainty about the appropriate reform path and hence reversals, relatively small ex ante reversal probabilities suffice to tilt the balance in favour of gradualism for a benevolent policymaker.

If policymakers are shortsighted because of political cycles they will never prefer big bang strategies to gradualism. Because of higher initial adjustment costs of a big bang 
strategy, the potential benefits from reform and FDI only materialize after the elections. The only possible countervailing argument stems from voter myopia. If voters react only to the economy's turning the corner, a big bang policy may offer better prospects for re-election. Still voter myopia brings mainly bad news for policymakers. Gradualist policymakers are never reelected. Big bang policymakers are unable to maintain power in case of a reversal. The only way to stay in power is to gamble for a big bang and then to have the luck not to make any major mistakes and hence avoid a reversal. But this may come at a high political and economic cost if a reversal occurs anyhow. All in all, it is not surprising that political instability has been a typical feature in transition and developing countries alike, and that economic reform is generally hard to achieve, for the political fruits of economic reform may be bitter. 


\section{References}

Alesina, A. and N. Roubini, 1992, Political Cycles in OECD countries, Review of Economic Studies, vol. 59(4), 663-88

Åslund, A., P. Boone, and S. Johnson, 1996, How to Stabilize: Lessons from Post-Communist Countries, Brookings Papers on Economic Activity, no.1, pp. 217-91

Bengoa, M. and B. Sanchez-Robles, 2003, Foreign direct investment, economic freedom and growth: New evidence from Latin America, European Journal of Political Economy, vol. 19 , pp. $529-45$

Berg, A., E. Borensztein, R. Sahay, and J. Zettelmeyer, 1999, The Evolution of Output in Transition Economies: Explaining the Differences, IMF Working Paper, WP/99/73, $81 \mathrm{p}$.

Borensztein, E., J. De Gregorio, and J-W. Lee, 1998, How does foreign direct investment affect economic growth?, Journal of International Economics, vol. 45, pp. 115-35

Campos, N., and F. Coricelli, 2002, Growth in Transition: What We Know, What We Don't, and What We Should, Journal of Economic Literature, XL, pp.793-836

Campos, N. and Y. Kinoshita, 2002, Foreign direct investment as technology transfered: Some panel evidence from the transition countries, Manchester School, vol. 70(3), pp. $398-419$

De Melo, M., C. Denizer, and A. Gelb, 1996, From Plan to Market: Patterns of Transition, World Bank Economic Review, 10(3), pp. 397-424

De Melo, M., C. Denizer, A. Gelb, and S. Tenev, 1997, Circumstance and Choice: The Role of Initial Conditions and Policies in Transition Economies, World Bank Policy Research Working Paper No. 1866

Dewatripont, M. and G. Roland, 1992, Economic Reform and Dynamic Political Constraints, Review of Economic Studies, vol. 59(4), 703-30.

Dewatripont, M. and G. Roland, 1995, The design of reform packages under uncertainty, American Economic Review, vol. 85(5), 1207-23

European Bank for Reconstruction and Development, EBRD Transition Report, London: $\mathrm{EBRD}$, various issues

Falcetti, E., M. Raiser and P. Sanfey, 2002, Defying the Odds: Initial Conditions, Reforms, and Growth in the First Decade of Transition', Journal of Comparative Economics, 30, pp. 229-50 
Fisher, S., R. Sahay, and C. Végh, 1996a, Economies in Transition: The Beginnings of Growth, American Economic Review Papers and Proceedings, 86(2), pp. 229-33

Fisher, S., R. Sahay, and C. Végh, 1996b, Stabilization and Growth in Transition Economies: The Early Experience, Journal of Economic Perspectives, 10(2), pp.45-66

Heybey, B. and P. Murrell, 1999, The Relationship between Economic Growth and the Speed of Liberalization during Transition, Journal of Policy Reform, vol. 3(2), pp. 121-37

Krueger, M. and M. Ciolko, 1998, A Note on Initial Conditions and Liberalization during Transition, Journal of Comparative Economics, vol. 26, pp. 718-34

Lensink, R. and O. Morrissey, 2001, Foreign direct investment: Flows, volatility and growth in developing countries, University of Groningen, SOM Research Report 01E16

Merlevede, B., 2003, Reform reversals and output growth in transition economies, Economics of Transition, vol. 11(4), pp. 649-69

Persson, T., and G. Tabellini, 2000, Political Economics: Explaining Economic Policy. Cambridge, Mass.: MITPress, 2000.

Roland, G., 2000, Transition and economics: Politics, markets and firms (Cambridge Ma: MIT Press)

Skogstad, S. and S. Everhart, 2001, Speed of Policy Reforms and Outcomes, American Economic Review Papers and Proceedings, Vol 87(2), pp. 58-62.

UNCTAD, Online FDI Database, www.unctad.org 


\section{A Appendix A: Data Issues}

Especially early in transition the decline in output is believed to be overestimated. Since statistical systems were originally designed to collect information from state-owned enterprises they probably failed to capture large parts of the emerging private sector. Additionally, the use of pre-transition relative prices resulted in low weights for newly emerging activities (Berg et al., 1999). Furthermore, both newly emerging activities and existing firms had an incentive to underreport output and sales to avoid taxes and regulation. Studies that use adjusted GDP data conclude that their results on growth determinants are not sensitive to the corrections to the data (See e.g. Loungani and Sheets, 1997 and Selowsky and Martin, 1997). Bearing these caveats in mind, we proceed using official data.

The aggregate reform index $(\mathrm{RI})$ is constructed as a weighted average of eight transition indexes as found in the EBRD's Transition Report. The indexes can take values between 1 and 4.3 with steps of about $\frac{1}{3}$. A score of 4.3 is a situation comparable to a market economy; a value of 1 denotes a centrally planned system. These indicators reflect the progress of reform with respect to $i$ ) price liberalization (weight 0.3 ), ii) trade and foreign exchange liberalization (weight 0.3 ), and $i i i$ ) privatisation, restructuring and financial market reform (weight 0.4) (see also De Melo et al. (1996)). The former two are directly available from the EBRD Transition Report, the latter is the average of six indices. A reversal is defined as a drop in the aggregate reform index, i.e. $\mathrm{RI}_{t}-\mathrm{RI}_{t-1}<0$. Clearly, the transition indexes are not perfect since they are subjective ratings. The ratings reflect the EBRD's assessment of both the effectiveness and extensiveness of policy measures, based on sometimes incomplete or imperfect information. Moreover macroeconomic performance has often already been observed at the moment of assessment, which is a source of possible endogeneity.

All data were rearranged in 'transition timing'. In order to identify common elements across countries of the post-communist economic cycle, we have to take into account the cycle's different starting points. Transition year $1(t)$ is then defined as the year in which communism and central planning were definitively abandoned. This is 1990 for Croatia, Hungary, FYR Macedonia, Poland and Slovenia; 1991 for Albania, Bulgaria, the Czech and Slovak Republic and Romania. For the Baltic States and the countries of the Former Soviet Union 1992 is taken to be the first year of transition. 


\section{Description}

$\Delta$ GDP Real GDP growth, domestic currency, annual percentage change

FB Fiscal balance, consolidated balance of general government, variable is negative if the balance is in deficit

INF End year inflation, transformed as $\ln (1+($ Inflation/100)

RI Reform index, see paper/Appendix A for construction

D Reversal dummy $=1$ if $\mathrm{RI}_{t}-\mathrm{RI}_{t-1}<0$

$\mathrm{IC}_{1,2} \quad$ Initial condition clusters

FS Freedom Status, average of political rights and civil liberties indexes; index ranges from 1 (free) to 7 (not free), original rating is inversed and rescaled $(1=$ free; $0.14=$ not free $)$ see also www.freedomhouse.org/research/freeworld/2000/methodology.htm

FDI FDI inflows in millions USD

\section{Data Sources}

$\Delta$ GDP IMF, World Economic Outlook Database

FB EBRD Transition Report

INF EBRD Transition Report

RI Own calculations based on indicators in EBRD Transition Report

D idem

$\mathrm{IC}_{1,2} \quad$ De Melo et al. (1997)

FS Freedom House

FDI UNCTAD online FDI Database 


\section{B Appendix B: Reversals and FDI inflows}

$$
\begin{aligned}
& \Delta G D P_{i, t}=\underset{(0.49)}{6.45}-\underset{(-1.74)}{19.69} R I_{i, t}+\underset{(3.06)}{15.82 R I_{i, t-1}}+\underset{(2.38)}{10.76} \Delta R I_{i, t} D_{i, t} R I_{i, t-1} \\
& +\underset{(5.20)}{0.93 t I C_{1}}-\underset{(-0.32)}{0.08} t I C_{2}+\underset{(2.91)}{0.27 G G B_{i, t}}+\underset{(2.50)}{5.82 F D I_{i, t}} \\
& \mathrm{R}^{2}=0.40 ; \chi^{2}=287.5^{* * *} ; \mathrm{n}=253 \\
& R I_{i, t}=\underset{(7.85)}{1.84}+\underset{(12.31)}{0.055} \Delta G D P_{i, t}-\underset{(-1.21)}{0.003} \Delta G D P_{i, t-1} \\
& +\underset{(3.21)}{1.00 F} F S_{i, t}-\underset{(-4.14)}{0.03} t I C_{1}+\underset{(0.44)}{0.005 t I C_{2}} \\
& \mathrm{R}^{2}=0.75 ; \chi^{2}=817.6^{* * *} ; \mathrm{n}=253 \\
& F D I_{i, t}=-\underset{(-0.70)}{0.59}+\underset{(3.54)}{1.22} R I_{i, t}+\underset{(4.20)}{1.13} N A T R E S+\underset{(5.06)}{0.14 t} \\
& -\underset{(-1.14)}{0.01} \Delta G D P_{i, t}-\underset{(-1.14)}{0.31} \Delta R I_{i, t} D_{i, t} R I_{i, t-1} \\
& \mathrm{R}^{2}=0.83 ; \chi^{2}=1275.6^{* * *} ; \mathrm{n}=253
\end{aligned}
$$




\section{DAVIDSON INSTITUTE WORKING PAPER SERIES - Most Recent Papers}

The entire Working Paper Series may be downloaded free of charge at: www.wdi.bus.umich.edu

CURRENT AS OF 12/6/2004

\begin{tabular}{|c|c|c|}
\hline Publication & Authors & Date \\
\hline $\begin{array}{l}\text { No. 732: Measuring the Institutional Change of the Monetary Regime } \\
\text { in a Political Economy Perspective }\end{array}$ & $\begin{array}{l}\text { Nikolay Nenovsky and Yorgos } \\
\text { Rizopoulos }\end{array}$ & Dec. 2004 \\
\hline $\begin{array}{l}\text { No. 731: Impact of Regulated Price Adjustments on Price Variability in } \\
\text { a Very Low Inflation Transition Economy: Case of Armenia }\end{array}$ & Aghassi Mkrtchyan & Nov. 2004 \\
\hline $\begin{array}{l}\text { No. 730: Reform, FDI and Economic Growth: Tale of the Tortoise and } \\
\text { the Hare }\end{array}$ & $\begin{array}{l}\text { Bruno Merlevede and Koen } \\
\text { Schoors }\end{array}$ & Nov. 2004 \\
\hline $\begin{array}{l}\text { No. 729: The Effects of Transition and Political Instability On Foreign } \\
\text { Direct Investment Inflows:Central Europe and the Balkans }\end{array}$ & $\begin{array}{l}\text { Josef C. Brada, Ali M. Kutan, } \\
\text { and Taner M. Yigit }\end{array}$ & Nov. 2004 \\
\hline $\begin{array}{l}\text { No. 728: Institutional Distance and International Business Strategies } \\
\text { in Emerging Economies }\end{array}$ & $\begin{array}{l}\text { Delia Ionascu, Klaus E. Meyer, } \\
\text { and Saul Erstin }\end{array}$ & Nov. 2004 \\
\hline No. 727: Explaining Patterns of Corruption in the Russian Regions & $\begin{array}{l}\text { Phyllis Dininio and Robert W. } \\
\text { Orttung }\end{array}$ & Nov. 2004 \\
\hline $\begin{array}{l}\text { No. 726: The Politics of Institutional Learning and Creation: Bank } \\
\text { Crises and Supervision in East Central Europe }\end{array}$ & Gerald A. McDermott & Nov. 2004 \\
\hline $\begin{array}{l}\text { No. 725: International Business and Development Economics: A } \\
\text { Winning Combination }\end{array}$ & Tamir Agmon & Nov. 2004 \\
\hline $\begin{array}{l}\text { No. 724: Importing High-Risk Capital and Revealing Hidden } \\
\text { Comparative Advantages }\end{array}$ & Tamir Agmon & Oct. 2004 \\
\hline $\begin{array}{l}\text { No. 723: Which entrepreneurs expect to expand their businesses? } \\
\text { Evidence from survey data in Lithuania }\end{array}$ & $\begin{array}{l}\text { is and Tomasz } \\
\text { icz }\end{array}$ & Oct. 2004 \\
\hline No. 722: Russia from Bust to Boom: Oil, Politics or the Ruble? & \begin{tabular}{|l|} 
Bruno Merlevede and Koen \\
Schoors \\
\end{tabular} & Oct. 2004 \\
\hline No. 721: Distanc & $\begin{array}{l}\text { Klara Sabirianova Peter, Jan } \\
\text { Svejnar, and Katherine Terrell }\end{array}$ & Sept. 2004 \\
\hline $\begin{array}{l}\text { No. 720: An Analysis of Gender Wage Differentials in Russia from } \\
\text { 1996-2002 }\end{array}$ & Rita Hansberry & Sept. 2004 \\
\hline $\begin{array}{l}\text { No. 719: Returns to Schooling in Russia and Ukraine: } \\
\text { A Semiparametric Approach to Cross-Country Comparative Analysis }\end{array}$ & $\begin{array}{l}\text { Peter and } \\
\text { nko }\end{array}$ & Sept 2004 \\
\hline $\begin{array}{l}\text { No. 718: The emergence of lar } \\
\text { firms: Evidence from Poland at }\end{array}$ & Irena Grosfeld and Iraj Hashi & Aug. 2004 \\
\hline $\begin{array}{l}\text { No. 717: Wage Determination Under Communism and In Transition: } \\
\text { Evidence from Central Europe }\end{array}$ & $\begin{array}{l}\text { Basu, Saul Estrin and Jan } \\
\text { ar }\end{array}$ & Aug. 2004 \\
\hline No. 716: The Evolution of Cross-Region Price Distribution in Russia & Konstantin Gluschenko & July 2004 \\
\hline $\begin{array}{l}\text { No. 715: Languages in the European Union: The Quest for Equality and } \\
\text { its Cost }\end{array}$ & $\begin{array}{l}\text { Jan Fidrmuc and Victor } \\
\text { Ginsburgh }\end{array}$ & July 2004 \\
\hline $\begin{array}{l}\text { No. 714: Voice of the Diaspora: An Analysis of Migrant Voting } \\
\text { Behavior }\end{array}$ & Jan Fidrmuc and Orla Doyle & July 2004 \\
\hline $\begin{array}{l}\text { No. 713: International Coercion, Emulation and Policy Diffusion: } \\
\text { Market-Oriented Infrastructure Reforms, 1977-1999 }\end{array}$ & $\begin{array}{l}\text { Witold J. Henis } \\
\text { Zelner and Mau }\end{array}$ & July 2004 \\
\hline $\begin{array}{l}\text { No. 712: Votes and Vetoes: The Political Determinants of Commercial } \\
\text { Openness }\end{array}$ & $\begin{array}{l}\text { Witold J. Henisz and Edward D. } \\
\text { Mansfield }\end{array}$ & July 2004 \\
\hline $\begin{array}{l}\text { No. 711: Interest Groups, Veto Points and Electricity Infrastructure } \\
\text { Deployment }\end{array}$ & $\begin{array}{l}\text { Witold J. Henisz and Bennet A. } \\
\text { Zelner }\end{array}$ & July 2004 \\
\hline $\begin{array}{l}\text { No. 710: Firms' Price Markups and Returns to Scale in Imperfect } \\
\text { Markets: Bulgaria and Hungary }\end{array}$ & \begin{tabular}{|l|} 
Rumen Dobrinsky, Gábor Körösi, \\
Nikolay Markov, and László \\
Halpern \\
\end{tabular} & July 2004 \\
\hline $\begin{array}{l}\text { No. 709: The Stability and Growth Pact from the Perspective } \\
\text { of the New Member States }\end{array}$ & Gábor Orbán and György Szapáry & July 2004 \\
\hline $\begin{array}{l}\text { No. 708: Contract Violations, Neighborhood Effects, and Wage Arrears } \\
\text { in Russia }\end{array}$ & $\begin{array}{l}\text { John S. Earle and Klara } \\
\text { Sabirianova Peter } \\
\end{array}$ & July 2004 \\
\hline $\begin{array}{l}\text { No. 707: Determinants of Employment Growth at MNEs: Evidence } \\
\text { from Egypt, India, South Africa and Vietnam }\end{array}$ & $\begin{array}{l}\text { Sumon Kumar Bhaumik, Saul } \\
\text { Estrin and Klaus Meyer }\end{array}$ & July 2004 \\
\hline
\end{tabular}

